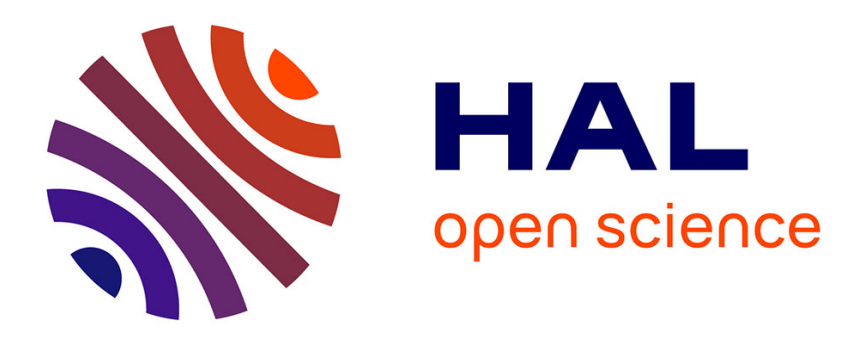

\title{
Conduction and breakdown in dielectric liquids
} J.P. Gosse

\section{To cite this version:}

J.P. Gosse. Conduction and breakdown in dielectric liquids. Revue de Physique Appliquée, 1987, 22

(9), pp.1034-1034. 10.1051/rphysap:019870022090103400 . jpa-00245640

\section{HAL Id: jpa-00245640 https://hal.science/jpa-00245640}

Submitted on 1 Jan 1987

HAL is a multi-disciplinary open access archive for the deposit and dissemination of scientific research documents, whether they are published or not. The documents may come from teaching and research institutions in France or abroad, or from public or private research centers.
L'archive ouverte pluridisciplinaire HAL, est destinée au dépôt et à la diffusion de documents scientifiques de niveau recherche, publiés ou non, émanant des établissements d'enseignement et de recherche français ou étrangers, des laboratoires publics ou privés. 


\section{Conduction and Breakdown in Dielectric Liquids}

\section{Foreword}

A conference on «Conduction and Breakdown in Dielectric Liquids » was held on March 13th and 14th 1986 in the "Laboratoire d'Electrostatique et de Matériaux Diélectriques», CNRS, Grenoble. There met the representatives of French industrial and universitary laboratories studying the electrical properties of liquids. Three themes were then considered :

a) liquid flow electrification and conduction at low and medium fields;

b) electrohydrodynamic phenomena and charge convection caused by space charges ;

c) mechanisms of charge creation at electrodes at very high fields and prebreakdown phenomena.

The papers forming this special issue are extended versions of the principal accounts. The guest lecturers were MM. Félici and Schmidt whose lectures are published in this Journal, and Mr. Goldman who has discussed corona and breakdown in gases. The reader is referred to a review on the subject (IEEE Trans. El. In. EI-17 (1982) 90-105).

After the Poitiers Seminar in 1983, essentially devoted to electrification and conduction, the Grenoble seminar has shown a general interest for prebreakdown phenomena.

On account of the success of this meeting, the organizers hope to convene in 1989 the representatives of a still wider range of French laboratories working on liquid state, its electrical properties and their applications.

J. P. Gosse 